22 Hogg JC, Macklem PT, Thurlbeck WM. Site and nature of airway obstruction in chronic obstructive lung disease. N Engl f Med 1968;278:1355-60.

23 Matsuba $K$, Thurlbeck WM. The number and dimension of small airways in nonemphysematous lungs. Am Rev Respir Dis 1971;104:516-28.

24 Matsuba K, Thurlbeck WM. The number and dimensions of small airways in emphysematous lungs. Am $\mathcal{F}$ Pathol 1972;67:265-76.

25 Petty TL, Silvers GW, Stanford RE. Functional correlations with mild and moderate emphysema in excised human lungs. Am Rev Respir Dis 1981;124:700-4.

26 Anderson AE, Foraker AG. Relative dimensions of bronchioles and parenchymal spaces in lungs from normal subjects and emphysematous patients. Am $\mathcal{F}$ Med 1962; 32:218-26.

27 Linhartova A, Anderson AE, Foraker AG. Nonrespiratory bronchiolar deformities. Arch Pathol 1973;95:45-8.

28 Linhartova A, Anderson AE, Foraker AG. Affixment arrangements of peribronchiolar alveoli in normal and emphysematous lungs. Arch Pathol Lab Med 1982;106: 499-502.

29 Silvers GW, Maisel JC, Petty TL, Mitchell RS, Filley GF. Central airways resistance in excised emphysematous lungs. Chest 1972;61:603-12.

30 Zamel N, Hogg JC, Gelb A. Mechanisms of maximal expiratory flow limitation in clinically unsuspected emphysema and obstruction of the peripheral airways. Am Rev Respir Dis 1976;113:337-45.

31 Thurlbeck WM. Pathology of chronic airflow obstruction. In: Cherniak NS, ed. Chronic obstructive pulmonary disease. Philadelphia: WB Saunders, 1991:3-20.

32 Cosio MG, Ghezzo $H$, Hogg JC, Corbin R, Loveland $M$, Dosman J, Macklem PT. The relations between structural changes in small airways and pulmonary function tests. $N$ Engl F Med 1978;298:1277-81.

33 Berend N, Thurlbeck WM. Correlation of maximum expiratory flow with small airway dimensions and pathology. Fournal Applied Physiology: Respiratory Environmental and Exercise Physiology 1982;52:346-51.

\title{
On sepsis and defining words
}

"Sepsis" and its adjectival form "septic" come from the Greek "sepein"-to make putrid. The relationship between sepsis, putrefaction, and smell is evident in such familiar terms as "antiseptic" (anything preventing the toxic action of microorganisms) and "septic tank" (where anaerobic bacteria putrefy and decompose waste). Medically "sepsis" is linked to its roots in bacterial putrefaction. The natural progression of smelly, festering wounds was described in antiquity by Hippocrates. In 1712 English physicians, ignorant of bacterial action, employed the term "antiseptick" for compounds that retarded putrefaction of corpses. By the mid 18th century "antiseptic" entered into lay vocabulary. This distinction between "septic" and "antiseptic" chemicals was the foundation for Lister, who developed the revolutionary concept of antiseptic surgery a century later.

German pathologists described late stage infection-when putrefaction set in-as "sepsis." By the early 1900s "sepsis" and its more common counterpart "septicaemia" were diagnostic terms describing patients who presumably absorbed poisons emanating from foul smelling foci.

Smell was an important factor in the diagnostic armamentarium of physicians at the turn of the century. Thus the most common use of sepsis-“puerperal sepsis"-described infections where lochial odour was diagnostic.

As a result of the large numbers of surgically treated traumatic wounds in the first world war "sepsis" and "septicaemia" gained greater popularity. With the identification of specific bacteria "septicaemia" became associated with systemic manifestations of staphylococcal and streptococcal infections.

The discovery of antibiotics became linked with a host of virtually indistinguishable terms to describe systemic infection such as bacteraemia, septicaemia, toxaemia, pyaemia, and sapraemia (same Greek derivation as sepsis). Between the world wars "sepsis" was relegated to describing local, rather than systemic, infections and the term was nearly abandoned.

The second world war saw widespread use of antibiotics and heightened interest in the treatment of shock, which researchers classified as cardiogenic, haemorrhagic, anaphylactic, or septic. In the Darwinian struggle for semantic survival "sepsis" possessed distinct advantages-its easy transition from noun to adjective and the smooth alliteration of "septic shock" describing bacterially induced hypoperfusion (imagine "pyaemic shock"). Pyaemia, sapraemia, and toxaemia all fell into disuse by the 1950 s.

One important reason for defining sepsis and related hard to define terms is to provide researchers with workable definitions to evaluate new treatments for serious infections. However, we will not soon read the last word on defining words. As linguist Jacques Barzun has aptly noted: "(word) usage is the most elusive of realities and defining is one of the most difficult acts of thought."

"Sepsis" connotes a diagnosis and severity of illness better than terms it has outlasted over the past century. The history of "sepsis" is one of the amorphousness of words, our perceptions of them, the phenomena they describe, and our attempts to control them. Where science and semantics intersect, the story of "sepsis" reinforces TS Eliot's admonition that ultimately the only wisdom we can hope to acquire is the wisdom of humility.

CORY FRANKLIN 